\title{
Transportation and Hydrology Studies of the U.S. Geological Survey in New England
}

The U.S. Geological Survey (USGS) has a long history of working with the Federal Highway Administration (FHWA) and State transportation agencies to provide data and information to address various issues related to water resources and the Nation's transportation infrastructure. These issues include the following:

- Streamgaging data networks

- Flow frequencies and flow statistics

- Water-quality investigations

- Bridge scour and sediment transport

- Hydrologic and hydraulic flood modeling

In New England, the USGS is conducting investigations to improve flood flow estimation techniques, to define channel characteristics at bankfull discharge, and to document storm tide as a result of major coastal storms. Current locally focused investigations include examination of flow frequency in rural, urban, and small watersheds; documentation of extreme inland floods along with flood-frequency updates; examination of the effects of roadway blasting on groundwater quality; and determinations of the effects of road salting on the quality of runoff and receiving waters.

\section{New Focus Areas for Science}

The USGS New England Water Science Center (http://newengland.water.usgs.gov/index.html) has identified five focus areas for new work with the FHWA and State transportation agencies in New England, including the Connecticut Department of Transportation (CTDOT), the Maine Department of Transportation (MEDOT), the Massachusetts Department of Transportation (MassDOT), the New Hampshire Department of Transportation (NHDOT), the Rhode Island Department of Transportation (RIDOT), and the Vermont Agency of Transportation (VTrans).

\section{Streamgaging Data Networks}

- Expand network coverage to include more small, urban, and steep watersheds

- Replace crest stage gages with recording stage gages to collect continuous data

- Add gages at critical transportation infrastructure

\section{Flow Frequencies and Flow Statistics}

- Ensure peak flow equations are updated regularly

- Determine potential effects of transportation infrastructure on quantity and quality of stormwater

- Define culvert slopes and velocities needed for fish passage at full range of flows

\section{Water-Quality Investigations}

- Define acute and chronic levels of constituents coming off of roadways and determine relative contribution to total maximum daily loads

- Develop empirical approaches for estimating chloride and sodium concentrations in dry weather snowmelt to estimate loading

- Use of the FHWA/USGS Stochastic Empirical Loading and Dilution Model (SELDM) for estimating concentrations and loads based on land use and impervious surfaces

\section{Bridge Scour and Sediment Transport}

- Develop regional equations for assessing risk of bridge scour

- Monitor peak flows and velocities for bridges at risk of scour

- Define bed movement in streams during high flow

\section{Hydrologic and Hydraulic Modeling}

- Increase flood inundation mapping with light imaging and detection (lidar)

- Improve understanding of high flows around structures through use of two-dimensional models.

- Improve ice jam assessment tools

- Enhance regional field calibration of friction values 


\section{Completed and Ongoing Projects}

Examples of recent investigations across New England in cooperation with Federal and State transportation agencies are presented below, along with respective publications where available.

\section{Streamgaging Data Networks}

The USGS has cooperated for many years with Federal and State transportation agencies to establish, maintain, and expand streamflow monitoring networks throughout New England. Information at http://newengland.water.usgs.gov/index.html.

\section{Flow Frequencies and Flow Statistics}

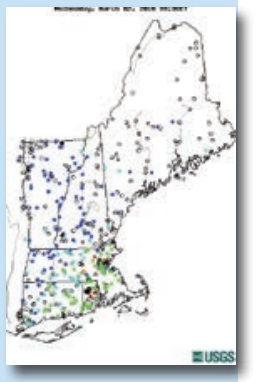

The USGS has worked with Federal and State transportation agencies to develop equations for estimating streamflow statistics with between 50 - and 0.2 percent annual exceedance probabilities (AEPs) throughout New England; these are equivalent to flows with between 2- and 500-year recurrence intervals, respectively. State transportation agencies have helped improve methods and equations for estimating peak flows for many years and have ensured that new streamgaging data are available throughout New England to support these updates.

\section{Flow Statistics in Maine}

The USGS, in cooperation with the MEDOT, derived equations to estimate monthly and annual mean streamflows and streamflows with 99- to 1-percent AEPs at streamgages and for ungaged rivers in Maine. Only streamflow data collected during recent years were used, thereby representing contemporary hydrologic conditions in Maine. Publication at http://dx.doi.org/10.3133/sir20155151.

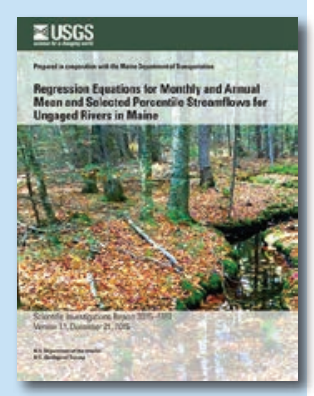

Flow Statistics in New Hampshire

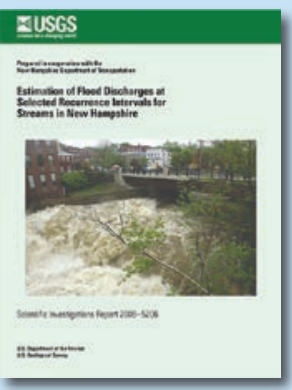

The USGS, in cooperation with the NHDOT, calculated flood flows with 50to 0.2-percent AEPs at streamgages in New Hampshire and developed equations to estimate flood discharges for ungaged, unregulated streams in New Hampshire. Publication at http://pubs.er.usgs.gov/ publication/sir20085206.
Flow Statistics in Rhode Island

The USGS, in cooperation with the Federal Emergency Management Agency (FEMA), calculated flood flows with 20- to 0.2-percent AEPs for streamgages in Rhode Island and developed equations to estimate flood flows for ungaged, unregulated streams in Rhode Island. Publication at http://pubs.er.usgs.gov/ publication/sir20125109.

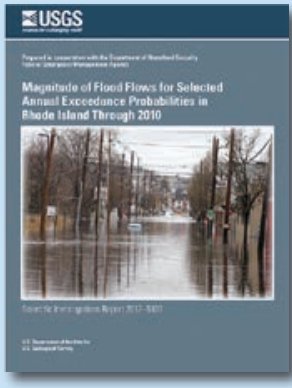

\section{Flow Statistics in Massachusetts}

The USGS is cooperating with the MassDOT to improve estimates of flood flows with 20- to 0.2-percent AEPs at streamgages and ungaged sites in Massachusetts.

\section{Peak Flow Regression Equations for Small, Ungaged Streams} in Maine

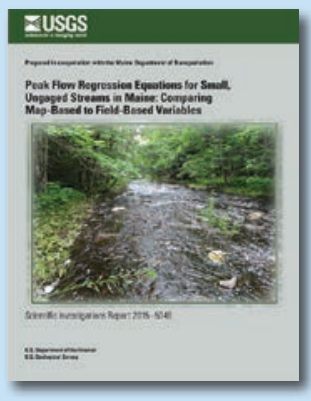

The USGS, in cooperation with the MEDOT, developed equations to estimate streamflows with 100- to 0.2-percent AEPs for small, ungaged streams in Maine. Publication at http://dx.doi.org/10.3133/sir20155049.

Flow Statistics in Vermont

The USGS, in cooperation with FEMA, calculated flood flows with 50to 0.2-percent AEPs for streamgages in Vermont and developed equations to estimate flood flows for ungaged, unregulated streams in Vermont.

Publication at http://dx.doi.org/10.3133/ sir20145078.

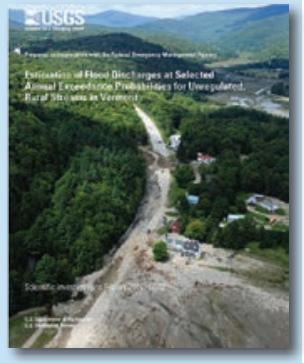

StreamStats-A Water-Resources Web Application

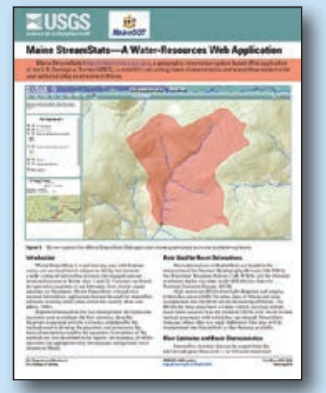

StreamStats (http://water.usgs.gov/ osw/streamstats/) is a tool that any user with Internet access can use to delineate quickly a basin and estimate a wide variety of streamflow statistics for ungaged sites on rivers and streams throughout New England. The USGS, in cooperation with the MEDOT, implemented StreamStats for Maine. Publication at http://dx.doi.org/10.3133/fs20153014. 


\section{Water-Quality Investigations}

Runoff and snowmelt from roadways, parking lots, and construction sites can convey sediment, nutrients, metals, deicing chemicals, and other constituents of concern. The quality and quantity of runoff from transportation infrastructure and other developed land uses are of continuing concern for transportation agencies, regulators, and interested citizens, especially in areas where runoff contributes to impaired waters or water supplies. The USGS, in cooperation with the FHWA and State transportation agencies across New England, has assessed flows, concentrations and loads of such constituents, the potential for adverse effects in receiving waters, and the potential effectiveness of mitigation measures for reducing these effects.

\section{Stormwater Runoff Discharge From Massachusetts Highways}

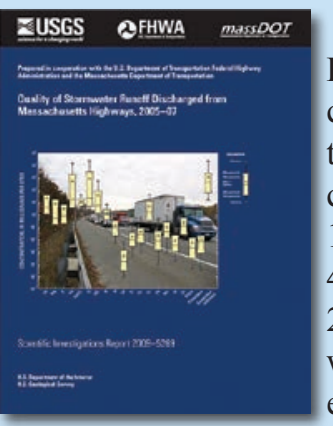

The USGS, in cooperation with the FHWA and MassDOT, characterized concentrations of sediment, nutrients, trace metals, deicing chemicals, and other constituents of concern in samples from 13 highway-runoff monitoring stations in 4 New England ecoregions from 2005 to 2007. Runoff volume and water quality was monitored for a total of 1,523 runoff events. Publication at

https://pubs.er.usgs.gov/publication/sir20095269.

Total Nutrients and Suspended Sediment in Stormwater Runoff From Bridge Decks in Eastern Massachusetts

The USGS is cooperating with MassDOT in an ongoing study to evaluate concentrations and loads of total phosphorus and suspended sediment from bridges in eastern Massachusetts over a 2-year period and the potential transferability of these data to other highway sites.

\section{Nitrate Contamination of Groundwater From Roadway Rock} Blasting in New Hampshire

The USGS in cooperation with the NHDOT performed a study to evaluate concentrations and isotopic compositions of nitrate and other nitrogen compounds in groundwater in response to roadway rock blasting. The study identified the sources of nitrogen (nitrate) contamination of groundwater and its appropriate mitigation at roadway rock blasting sites.

\section{Publication at http://dx.doi.org/10.1021/} acs.est.5b03671.

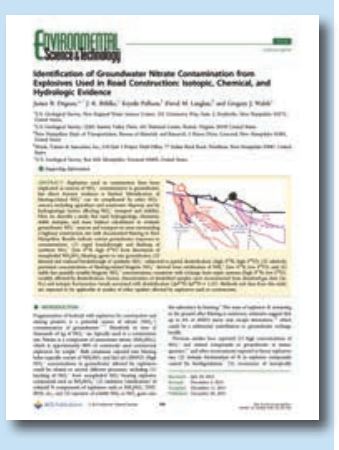

zumer
Chloride Concentrations in Streams Along Interstate 95 in Southeastern Connecticut

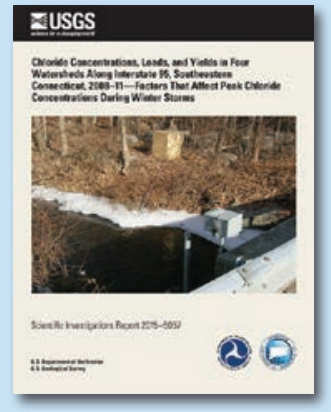

The USGS, in cooperation with the FHWA and the CTDOT, evaluated the effects of road-deicer applications on stream water-quality upstream and downstream of Interstate 95 (I-95) in four small watersheds in southeastern Connecticut from 2008 to 2011. Publication at https://pubs.er.usgs.gov/ publication/sir20155057.

Chloride Concentrations in Streams Along State Highways in Northwestern Vermont

The USGS, in cooperation with the VTrans, quantified changes in concentrations and loads of road-deicing chloride upstream and downstream of highway bridges in three small watersheds in Chittenden County from 2005 to 2008. Publication at http://pubs.er.usgs.gov/publication/ sir20095236.

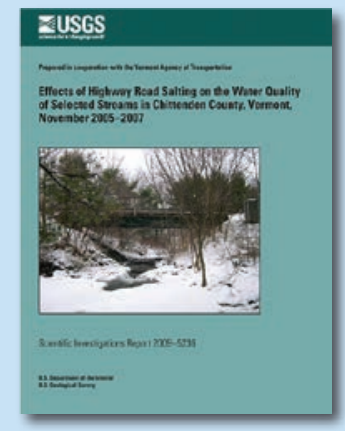

\section{Pollutant Loadings Model for Highway Stormwater Runoff}

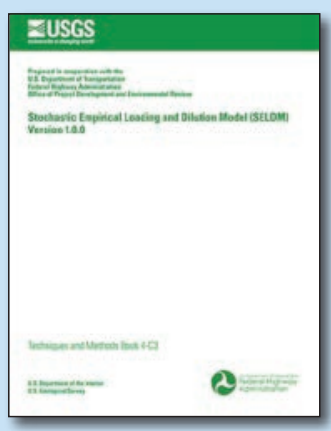

The USGS, in cooperation with the FHWA, developed the SELDM, which uses available data and stochastic Monte Carlo methods to generate planning-level estimates of event mean concentrations, discharges, and loads from highways or other land uses and in the receiving waters upstream and downstream of the highway-runoff outfall by mass-balance methods. Estimates can be used to evaluate highway-runoff discharges as a potential source of water-quality constituents, the potential effects of runoff loads on receiving water quality, and the potential effectiveness of best management practices for reducing the effects of highway runoff on receiving waters. Publication at http://pubs.er.usgs.gov/publication/tm4C3.

\section{Additional Water-Quality Publications}

Publications at http://webdmamrl.er.usgs.gov/g1/FHWA/FHWAHEP-09-004/FHWA-HEP-09-004.pdf, http://dx.doi.org/10.3133/ sir20145037, http://pubs.er.usgs.gov/publication/sir20125110, and http://pubs.er.usgs.gov/publication/sir20125205.

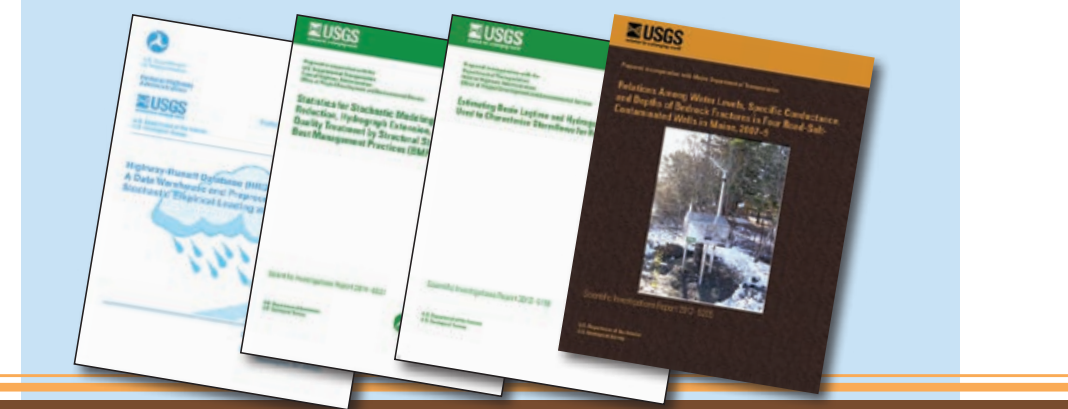




\section{Bridge Scour and Sediment Transport}

The USGS has worked with Federal and State transportation agencies to develop techniques and data to measure and quantify bridge scour in New England and across the Nation through the National Bridge Scour Program (http://water.usgs.gov/osw/techniques/bs/sed.bs.html). Publications at http://pubs.er.usgs.gov/publication/sir20085099 and http://pubs.er.usgs.gov/publication/wri004035.

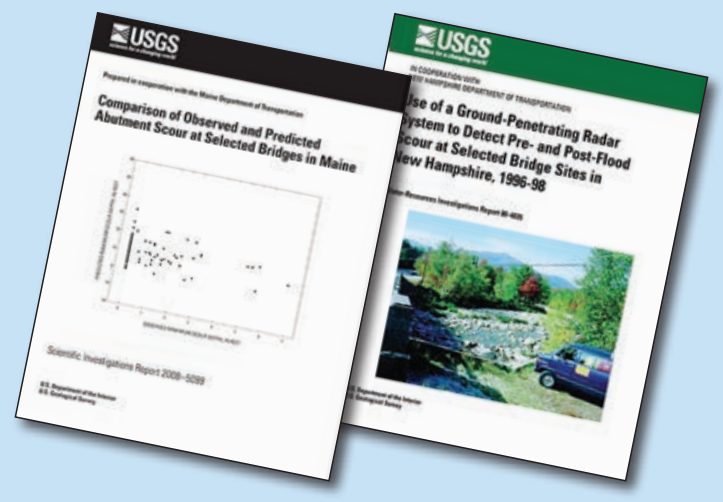

\section{Hydrologic and Hydraulic Modeling}

Flood Study for the Cold River and Warren Brook, New Hampshire

The USGS, in cooperation with the NHDOT, prepared flood elevations for the Cold River and Warren Brook to aid in the replacement of infrastructure damaged during the flood of October 8-9, 2005, and to provide data for updating future flood maps. Publication at http://pubs.er.usgs.gov/publication/ ofr20061313.

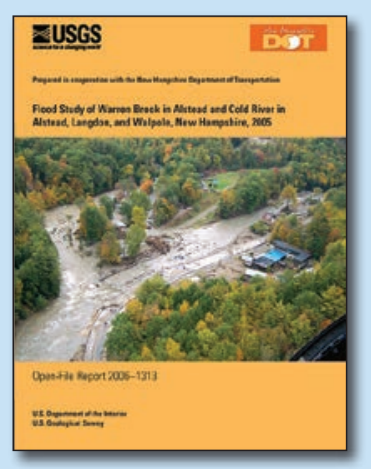

Additional Hydrologic and Hydraulic Modeling Publications

Publications at http://pubs.er.usgs.gov/publication/sir20135080 and http://dx.doi.org/10.3133/sir20145146.

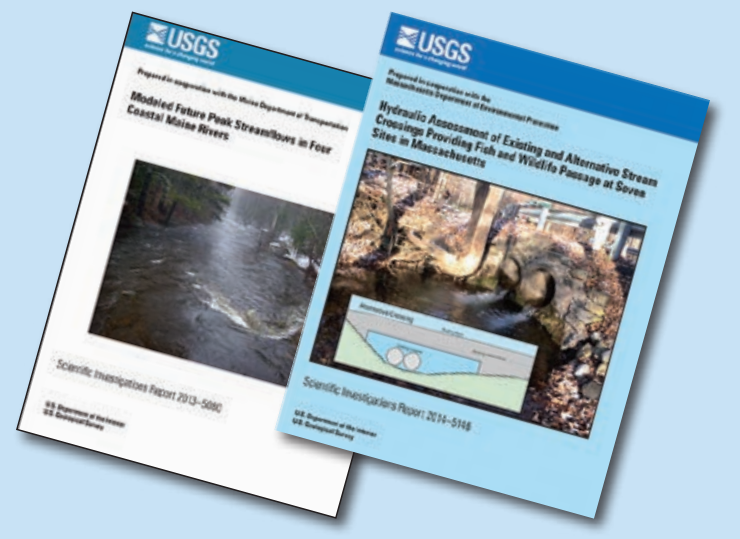

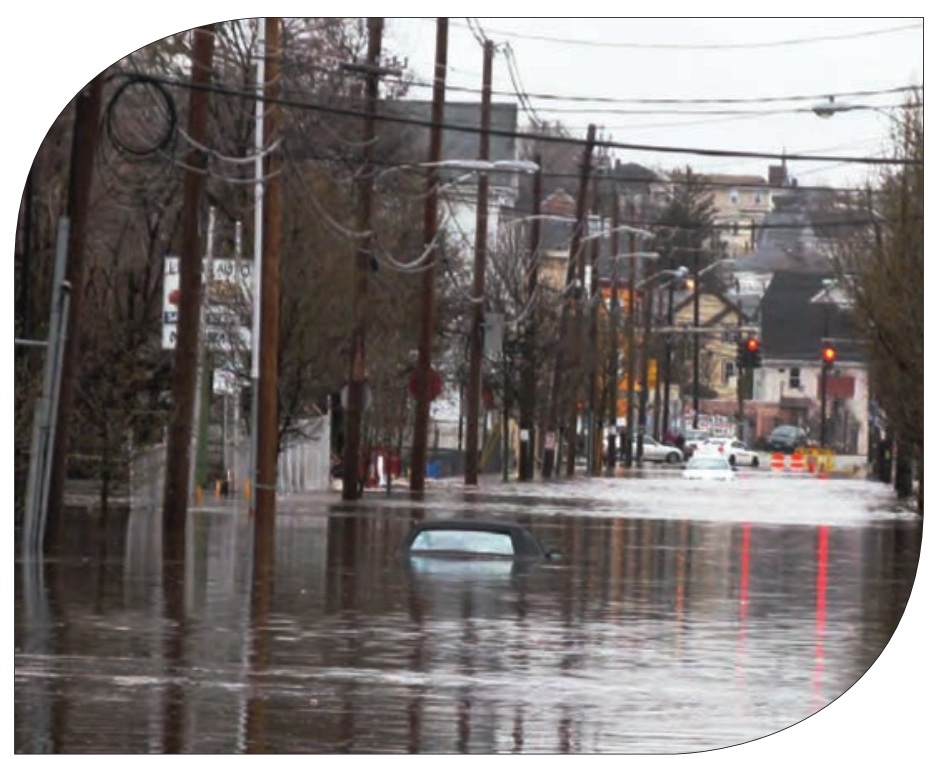

Flooding in March and April 2010 along the Woonasquatucket River at Valley Street in Providence, Rhode Island, looking northward toward Atwells Avenue (traffic light) from Helme Street. Photograph by the U.S. Geological Survey.

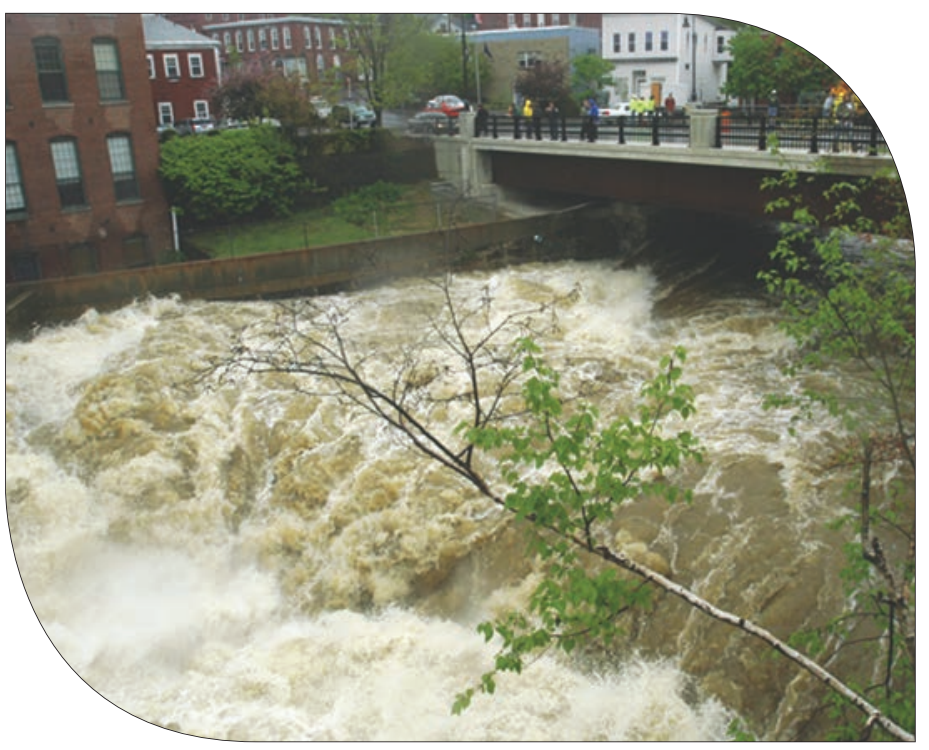

The Suncook River at Main Street in the Village of Suncook, New Hampshire, during the flood of May 2006. Photograph by the U.S. Geological Survey.

\section{For more information, contact:}

Director, New England Water Science Center

U.S. Geological Survey

331 Commerce Way, Suite 2

Pembroke, NH 03275

Email: dc_nweng@usgs.gov

or visit our Web site at

http://newengland.water.usgs.gov/ 